\title{
Framing, adapting, and applying: Learning to contextualize science activity in multilingual science classrooms
}

\section{Introduction}

In this article, we turn our attention to a long-standing focus of global science education reform efforts: context-based approaches to science instruction. We share what we have learned about introducing changes in a set of secondary science teacher education programs for these contextbased approaches to science instruction. These insights and ideas stem from our previous work (Tolbert, Stoddart, Lyon, \& Solis, 2014; Lyon, Tolbert, Solis, Stoddart, \& Bunch, 2016; Lyon, Stoddart, Bunch, Tolbert, Salinas, \& Solis, 2018; Tolbert \& Knox, 2016) and our exploration of pre-service teachers' practices in our program. Contextualizing Science Activity is one of the key practices of the SSTELLA instructional framework. In this article, we direct attention to our learning about teaching pre-service science teachers to contextualize instruction, a practice that is especially important for both language and literacy acquisition and science learning.

Global organizations such as UNESCO have increasingly advocated for education reforms that reflect and respect local contexts, traditions and values (UNESCO, 2016). Furthermore, there is a growing consensus that education, including science education, should be contextualized in ways that attend to current and future challenges of wicked problems such as climate change, economic inequality, technological shifts (biotech, artificial intelligence, etc) (Organisation for Economic Cooperation and Development [OECD], 2018; Tolbert \& Bazzul, 2017). Contextualizing science instruction can be broadly understood as creating relevant contexts for language and science learning (King 2012; Krashen 2013; Rivet \& Krajcik 2008; Rosebery \& Warren 2008). A fundamental tension many educators must consider is the extent to which instruction is 'relevant' for both socio-scientific problem solving, as well as 'relevant' to the lived experiences of students, particularly those who are Emergent Bilingual Learners (EBLs) ${ }^{1}$ in multilingual classrooms.

We understand that secondary science teachers have few or no opportunities to become well prepared for socially and culturally contextualized instruction since science teacher preparation often privileges western science content and skills over social and cultural contexts (Rodriguez \& Kitchen 2005) - while both novice and experienced teachers feel underprepared to teach EBLs (Banilower et al., 2013; Gándara, Maxwell-Jolly \& Driscoll 2005; Lucas \& Grinberg 2008). We aim to address this opportunity gap by communicating our conceptualization of a contextualized pedagogy for EBLs in science. We also aim to illustrate the complexities of our efforts to support novice teachers in enacting contextually authentic science learning experiences for students in multilingual secondary classrooms. We articulate, based on our experience, how science teacher

\footnotetext{
${ }^{1}$ Following Ofelia Garcia (2009), we use the term Emergent Bilingual Learners to describe students who are learning a language other than their home language. Garcia argues that the term Emergent Bilingual Learners honors the fact that EBLs are developing bilingual proficiencies, rather than proficiency exclusively in one (dominant) language, such as English.
} 
education programs can be re-articulated to better prepare science teachers for contextualized instruction.

In this article, we first briefly describe our instructional framework, SSTELLA, and how we used it to guide modifications to our teacher education practice. Then, we focus on the SSTELLA practice of Contextualizing Science Activity. Next, we share the learning continuum we have developed to better understand and support novice teacher learning in relation to this practice, which, in turn, supported our analysis of the contextualizing practices of novice teachers in secondary science classrooms. We conclude with a discussion of what we have learned, as practitioners in science teacher education, about the struggles novice teachers face in contextualizing science activities. We reflect on how we could better support future novice teachers in order to both construct relevant socio-scientific frames for learning, as well as elicit and apply EBL students' lived experiences across scientific disciplines.

\section{The SSTELLA Instructional Framework}

The Secondary Science Teaching with English Language and Literacy Acquisition (SSTELLA) Instructional Framework builds on previous projects addressing the need for more responsive and inclusive science teacher education (Bravo, Mosqueda, Solís, \& Stoddart 2014; Stoddart, Bravo, Mosqueda \& Solís 2013; Stoddart, Solis, Tolbert, \& Bravo 2010). These projects aimed at collaboratively redesigning initial/preservice science teacher education programs in ways that addressed the synergistic relationships between language and science learning, and supported students' productive use of science language in authentic disciplinary contexts. These prior projects were focused on elementary science instruction and elementary teacher education. The SSTELLA Framework extended this work into secondary science instruction and secondary teacher education (Tolbert et al., 2014; Lyon et al., 2016). SSTELLA attends to the relationships among science, language, and sociocultural contexts through four dimensions of instruction: Contextualizing Science Activity, Scientific Sense-making, Scientific Discourse, and Language and Literacy, referred to as the SSTELLA Instructional Framework (Tolbert et al., 2014). Evidence from our work has shown how novice teachers' practices in multilingual classrooms are supported by the SSTELLA Framework, particularly those related to student talk, student interaction, and literacy (Lyon et al., 2018).

While Emergent Bilingual Learners are often left to 'sink or swim' in decontextualized secondary science courses--or denied access to secondary science courses altogether (Callahan, 2005; Iddings, Combs, \& Moll, 2012; Markos, 2012) — we see how the SSTELLA Framework can be a form of pedagogical resistance against this deficit narrative by supporting teachers to learn and use the four interrelated practices in science classrooms with EBLs. In Scientific Sense-Making practices, teachers structure opportunities to learn around clearly communicating core ideas in science, where students explore those core ideas through scientific practices. Teachers support student use of Scientific Discourse, so that students learn how to both construct and analyze 
scientific arguments and explanations in the context of understanding core ideas. At the same time, teachers attend to Language and Literacy Development, providing additional supports for EBLs through extensive student interaction, scaffolds for vocabulary development,; and engagement with reading, writing, and discussing multiple forms of scientific texts. Contextualizing Science Activity represents the "doorway" that expands (or opens) EBLs' opportunities to engage more fully with other instructional practices: teachers contextualize to both support students' development of more complex science understandings as well as students' development of disciplinary language practices (See Figure 1).

Figure 1. The SSTELLA Instructional Framework.

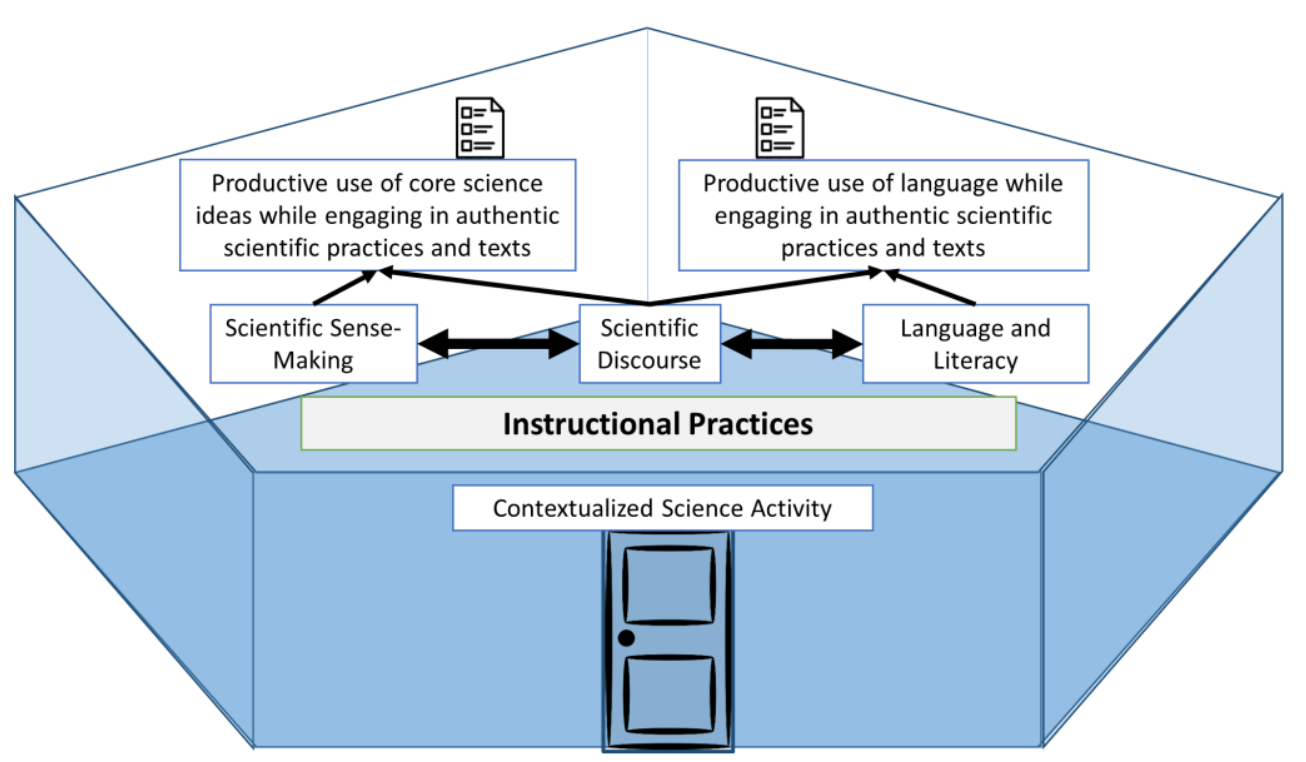

\section{Contextualizing Science Activity}

Contextualizing Science Activity is an essential practice to both language acquisition (Krashen 1982) and scientific sense-making for EBLs (e.g., Rosebery \& Warren 2008), whereby students use multiple language forms and discourses, e.g., everyday, formal scientific, formal classroom discourses, peer discourses, etc., to grapple with real world problems and issues. Making the content comprehensible through engaging and relevant contexts is essential to language acquisition, reducing the anxiety that language learners experience when grappling with new 
vocabulary and language forms. Learners are better situated to persevere through the complexities of language learning when engaged with relevant and interesting problems or issues (Krashen 2013). Contextualizing science instruction also helps students better understand relationships between school science learning and their lived experiences, and connections between science and societal issues (National Science Teachers Association 2010).

Contexts for science-related problems can have a global as well as a local reach, with the goal of engaging students in the service of understanding and even developing solutions for local issues, particularly those that disproportionately affect minoritized communities. Contextualization can also provide opportunities for students to connect science ideas to their home countries and cultural practices, creating mutually beneficial learning experiences for EBLs as well as their teachers and their fellow students.

In the SSTELLA Framework, Contextualizing Science Activity is informed by sociocultural approaches to science and language instruction, with a focus on facilitating meaningful learning contexts for/with EBLs (see Tolbert, 2016, for a more detailed explanation of the sociocultural approaches that have informed Contextualizing Science Activity). We have elaborated the concept and expanded the practice into two sub-dimensions of Contextualizing Science Activity, (1) Framing and (2) Adapting and Applying.

In Contextualizing Science Activity, when planning for meaningfulness and relevance in science, teachers think carefully about how to frame the unit or lesson using an overarching driving question or real-world problem. The goal is to facilitate scientific sense-making and language and literacy development in the context of science-related social issues or locally relevant phenomena. The overarching driving question or problem should contextualize the big idea of the lesson, which might otherwise be inaccessible to EBLs, given the abstract nature of many secondary science concepts and technical terms (Cummins, 1991; Stoddart et al., 2002). Students develop scientific understandings as they grapple with the question or problem.

The teacher elicits, and adapts and applies student contributions throughout the lesson, helping students see connections between their contributions and the learning goals and also by encouraging students to explore their own connections between the learning goals and relevant personal, local, and/or global contexts - all of which are essential to meaning making. Students contribute their own funds of knowledge, as well as build on and respond to similar contributions from their peers, so that knowledge is co-constructed and mediated through multiple perspectives. In this sense, Contextualizing Science Activity helps create meaningful opportunities for scientific sense-making and productive language use, whereby teachers ideally leverage contextualized science activities to facilitate student sharing, collaboration and dialogue-fundamental to both science learning and language development. 


\section{Context for our Work}

As a team, we conducted our intervention across four teacher education programs in different locations of the United States of America (see Tolbert et al., 2014; Stoddart, Solis, Lyon, \& Tolbert, 2017). We employed a quasi-experimental design, in which we collected data from a baseline comparison cohort of pre-service science teachers during their un-restructured teacher preparation program and into their first two years of full-time science teaching. We then compared this group to pre-service teachers who completed their program at the same institutions the following year and who received instruction based on the SSTELLA Instructional Framework (Fig 1). These changes in teacher education practice consisted of (1) a redesigned SSTELLA-informed secondary science method course and (2) mentorship during student teaching field experiences, whereby pre-service teachers were paired with cooperating teachers and university supervisors who attended SSTELLA mentor teacher workshops. This group of pre-service teachers was also followed into their first and second years of teaching. We conducted this study in order to assess the effects our teacher education practices on how science teachers taught in more inclusive ways in their classrooms.

\section{Contextualizing Science Activity and Novice Teacher Learning}

Evidence from prior research on teacher preparation has consistently demonstrated that contextualizing science instruction is the least observed instructional practice of those that have been identified as integral to culturally responsive science teaching (Bravo et al., 2014; Lyon et al., 2018; Patchen \& Cox-Petersen, 2008; Stoddart et al., 2013; Stoddart \& Mosqueda, 2015; Teemant, Wink, \& Tyra, 2011) — even when preservice teachers' beliefs about contextualizing activity are largely positive (Bravo et al., 2014). The task for us as science teacher education practitioners and researchers is both to better understand the particular challenges associated with contextualizing instruction, and to find ways to support novice teachers in developing and refining their abilities to contextualize science activities in multilingual classrooms.

Given what we have learned about contextualization from our research (Bravo et al., 2014; Lyon et al., 2018; Stoddart et al., 2013), we have developed several approaches to support teacher learning in these areas. We are currently exploring how these approaches work, how they impact novice teacher practice, and how they correlate with opportunities to learn for EBL students. We have teamed with science teacher educators, mentor teachers, and university supervisors across four institutions to share views on contextualization, its importance, and collaborate in developing ways to better support novice teachers to implement contextualized science activities in their practice. The resources we have developed and shared in professional development and methods course sessions are designed to support participants (e.g., teacher educators, novice teachers, supervisors) in noticing (through video), experiencing (through participating in actual contextualized lesson activities), and approximating (through practicing contextualizing science activity in microteaching and student teaching) contextualized science activities. These resources 
include teaching videos, methods course lesson activities, and anchor assignments, and are key to the development of novice teachers' understandings and practices related to contextualization in science learning and language development with EBLs (Buxton \& Allexsaht-Snider, 2016).

As an example, in one of our video resources, a novice (first-year) science teacher in a high school biology class, with both English proficient students and EBLs, introduces a fairly decontextualized mini unit on geological time. While the lesson integrates several literacy support strategies (such as jigsaw), students' lived experiences are not elicited or leveraged in the service of science learning. Rather, students are first asked to pin a series geological events (e.g., first aquatic life, dinosaurs' appearance, earliest humans, formation of Pangaea) to a blank geological timeline hanging up on a classroom wall for all to see. Then, students work in groups of four to each read a formal scientific text about one of four different geological eras (Precambrian, Paleozoic, Mesozoic, Cenozoic) and then use a four-square note-taking sheet to record key ideas from each reader. Finally, students are asked to reorder the events on the classroom timeline based on what they learned from the readings.

In another example, which is contextualized and a follow up to the first example, taking place in the same classroom, the teacher had asked students to interview family members about two to three personal historical events: One important personal event that occurred before the student was born, one that occurred while the student was in primary school, and one that occurred more recently. The teacher then asked students to write those experiences down in his/her science notebook. Volunteers were asked to share those experiences with the class, and then all students create a timeline from their personal historical events. After creating timelines, the teacher had students communicate their personal historical events with each other, practicing sequential language and interpreting timelines using their own stories. This activity was a segue into learning about geological events during the Cambrian explosion and using sequential language to communicate those events.

Preservice teachers in our SSTELLA science methods courses deconstructed these and other video cases and related activities from the perspective of relevance, language use, and scientific sensemaking. In the above example, preservice teachers, mentor teachers, and science methods instructors noticed a distinct difference in the levels of student talk, engagement, and participation in the contextualized video versus the decontextualized example. The video resources and related experiential activities facilitated reflection upon the opportunities of each scenario for students in multilingual classrooms, with a focus on EBLs, to use language productively, while making sense of complex scientific and socio-scientific ideas through meaningful contexts that leverage EBL students' lived experiences. Preservice teachers also documented, shared, and deconstructed examples and non-examples of contextualized practices from observations of mentor teachers in field placement classrooms, and then collaborated to generate ideas regarding how to more authentically contextualize the non-examples. Finally, they constructed their own contextualized 
lessons and implemented them through microteaching, with feedback from their peers, in their science teacher education courses before implementing them in the field, with feedback from mentor teachers and supervisors who had shared with the research team the mentoring institute.

\section{Analyzing Practice}

As part of our research and development project, we developed the SSTELLA's Practices Progression (see Fig 2), a tool which both science teacher educators and mentor teachers participating in the project are using to help novice teachers reflect on their own classroom practices in relation to the framework (Tolbert et al., 2014). Figure 2 represents the progression for Contextualizing Science Activity (the full progression for all SSTELLA dimensions is in Lyon et al., 2016). Figure 2 illustrates the practices of Framing and Adapting/Applying at the three different levels of implementation.

Figure 2. SSTELLA's Practices Progression: Contextualizing Science Activity 


\section{CONTEXTUALIZING SCIENCE ACTIVITY}

Framing

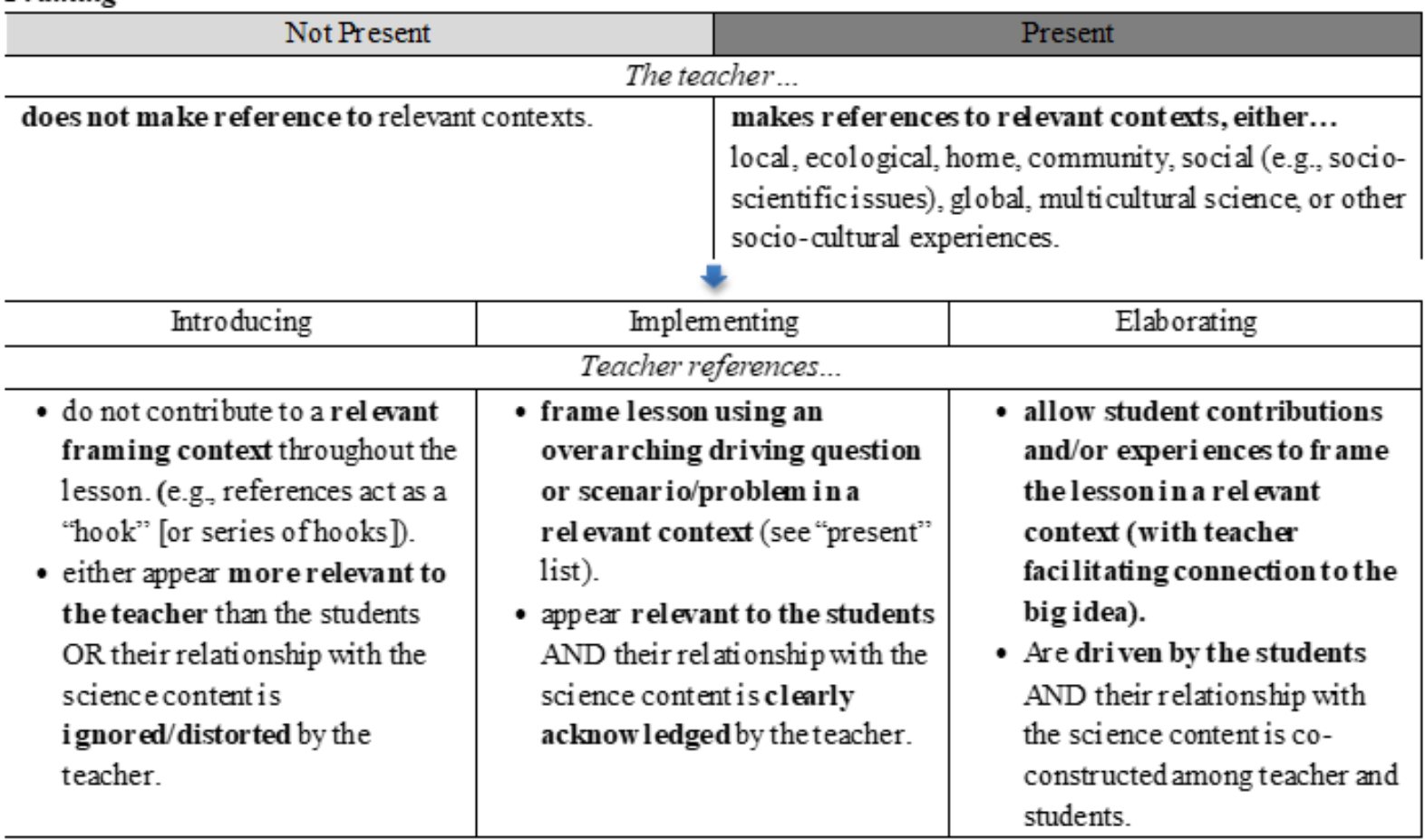

Adapting \& Applying

\begin{tabular}{|c|c|c|c|}
\hline \multicolumn{2}{|l|}{ Not Present } & \multicolumn{2}{|r|}{ Present } \\
\hline \multicolumn{4}{|c|}{ The teacher... } \\
\hline \multicolumn{2}{|c|}{$\begin{array}{l}\text { does not provide opportunities for students to } \\
\text { contribute their lived experiences or funds of } \\
\text { knowledge. }\end{array}$} & \multicolumn{2}{|c|}{$\begin{array}{l}\text { provides opportunities for students to contribute their } \\
\text { lived experiences or funds of knowledge. }\end{array}$} \\
\hline \multicolumn{4}{|c|}{ 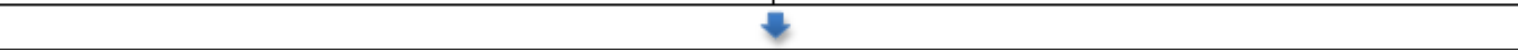 } \\
\hline Introducing & & nenting & Elaborating \\
\hline \multicolumn{4}{|c|}{ Teacher... } \\
\hline $\begin{array}{l}\text { acknowledges students' } \\
\text { contributions, but does not } \\
\text { connect them to science learning. }\end{array}$ & $\begin{array}{l}\text { elicits } \\
\text { contrib } \\
\text { and rel } \\
\text { ecolog } \\
\text { social [ } \\
\text { issues] } \\
\text { science } \\
\text { experie }\end{array}$ & $\begin{array}{l}\text { ects student } \\
\text { science content } \\
\text { texts (local, } \\
\text { e, community, } \\
\text { o-scientific } \\
\text { multicultural } \\
\text { r socio-cultural }\end{array}$ & $\begin{array}{l}\text { facilitates opportunities for } \\
\text { students to build on and } \\
\text { respond to peer contributions, } \\
\text { and explicitly encourages } \\
\text { students to connect contributions } \\
\text { to science learning and rel evant } \\
\text { contexts. }\end{array}$ \\
\hline
\end{tabular}


The levels of implementation are meant to represent distinctive features of observable classroom practice as a heuristic for understanding how our teachers learn to contextualize science teaching within these two sub-dimensions, from a not-present level to an introduction level to an elaboration level. An elaboration level implies a practice where lessons are framed within references to relevant contexts, and students are given the opportunities to contribute their experiences in ways than can productively change the direction of a lesson towards connecting science content with student-generated contexts for learning.

We focus now on our learning from two cases of classroom practice from preservice teachers. We use these cases to discuss the challenges we experience as we learn to support novice teachers in contextualizing science activity in multilingual secondary classrooms.

\section{Learning from Cases of Novice Teacher Practice}

For this article, we have purposefully selected two video-recorded teaching events that represent the types of approaches to Contextualizing Science Activity that are reflective of our challenges to support pre-service teachers in practice (Lyon et al., 2018). The first case is Mr. Ramos (pseudonym), a novice teacher from the baseline cohort of this study, who did not participate in the re-structured science methods course during his teacher education. The second case is Ms. Ziegler (pseudonym), who participated in the redesigned science methods course during her preparation program.

In the following sections, we describe each of these two teaching events: Mr. Ramos's chemistry lesson on chemical reactions, and Ms. Ziegler's biology lesson on immunity. For each event, we provide contextual information about the teacher, the students, and the classroom to situate the lesson. Then, drawing from lesson video recordings, debrief interviews with each preservice teacher, and field notes from the observation, we describe the lesson. Following our presentation of the cases, we discuss what we can learn from analyzing the classroom practices of novice teachers, and explore implications for improving teacher preparation for contextualizing science activity in multilingual classrooms more broadly.

\section{Mr. Ramos}

Mr. Ramos is a Mexican American student teacher in his early twenties. His student teaching experience occurred in a large urban high school serving predominantly Latino/a students, which happens to be the same one he graduated from. This high school is located in a community that lies adjacent to an active air force base that was found in the 1950s to have discarded contaminants including solvents and paint strippers, waste oil spills, petroleum spills, metal plating wastes,

hydraulic fluids, and radiological wastes. This finding of significant water and soil contamination lead to the establishment of the area as an Environmental Protection Agency (EPA) Superfund 
site $^{2}$. By the time of this designated site, it was estimated that at least 10,000 people obtained drinking water from the base and surrounding private wells in the area of the contamination. Mr. Ramos requested to do his student teaching here in the high school from which he graduated and in the community where he and his extended family live. Mr. Ramos teaches a chemistry course for sophomores, juniors, and seniors. According to the data we gathered, twenty-three students are Latino/a, five are Black, and two are White. Two students are officially designated as EBLs. Students are seated in pairs at long tables, all facing the front of the room.

The lesson we describe below is the first in a unit on chemical reactions and chemical equations. Mr. Ramos began the lesson presenting the big idea of the lesson. On the whiteboard he wrote: "What is a chemical equation and what is a chemical reaction?" The students began class with a bellwork ${ }^{3}$ activity. In it, Mr. Ramos asked them to define "What is an equation?" using their own words, and to provide an example. After giving students a few minutes to complete the activity, Mr. Ramos led a discussion about the bellwork question with the whole class in which a few students shared their examples. Students offered examples from math, such as: " $3 x+2=0$." Mr. Ramos probed their answers with questions such as "but what is a chemical equation, what does it explain?" One student suggested: "A formula for a chemical reaction." Another student shared: "an equation can be used to figure out distance." Mr. Ramos then led the students in a discussion about differences between a mathematical equation and a chemical equation. He followed by asking them to think specifically about what a chemical equation is "describing." Students suggested things like "a chemical process", and one student volunteered: "A chemical reaction." Mr. Ramos then asked students again for an example of a chemical reaction. One student suggested "Sn $+\mathrm{CO}_{2}=\mathrm{Sn}\left(\mathrm{CO}_{2}\right)$ ". Mr. Ramos wrote this response on the board, asked the class if it was correct, and then told them they will see it later in this unit.

Mr. Ramos then continued by asking students, "What makes this an equation?", referring to the chemical reaction equation noted earlier. Some students replied, "the equal sign", and then he asked, "why do you think this is also a chemical reaction?" Several students responded with ideas such as a "change in properties" and a "change in the chemicals." Mr. Ramos then wrote down the definition of a chemical equation: "A chemical equation is the symbolic representation of a chemical reaction wherein the reactant entities are given on the left-hand side and the product entities on the right-hand side." Mr. Ramos asked students to read the definition aloud, and then requested one student to interpret the definition based on the example written on the board. He then asked, "Where are reactants in the example equation?" A student volunteered to go to the whiteboard and circle the reactant in the equation. Mr. Ramos requested another student do the same for the product, while mentioning that reactants are on the left side and products on the right

\footnotetext{
2 An EPA Superfund site is a denomination given by the United States EPA to locations that had received contamination requiring long-term responses to be cleaned from pollutants.

${ }^{3}$ Bellwork is a classroom routine in which students complete a short activity during the first 5 to 10 minutes of class.
} 
side. Mr. Ramos then elicited everyday language/definitions for the words symbolic, reactant, and product Mr. Ramos wrote down the definitions offered by students which included symbolic, "something that stands for something else," reactant, "a chemical that causes something to happen like a reaction to happen;" and product, "the result, the outcome". Throughout the discussion he would erase and revise these definitions as students added to and modified their ideas.

Afterwards, Mr. Ramos led students in a discussion about differences between a chemical equation and a chemical reaction, and then returned to having students think about chemical reactions. He asked students, "besides color, what else indicates that a chemical reaction has taken place?" Students responded that evidence can include "bubbles," "heat," and "light." Then Mr. Ramos asked if fireworks or a fire would indicate a chemical reaction, acknowledging "yes" answers from the students. After a discussion of an additional indicator (formation of a precipitate), Mr. Ramos described each indicator in detail, and encouraged students to share examples from everyday life or a past laboratory experience. He prompted students with an example "when you drop salt in water, is that a chemical reaction? How do you know?" Some students answered "no, because you can separate them." He then provided more examples, such as rusting and color change, and referenced the Statue of Liberty's change in color as a chemical change. Mr. Ramos also asked students to evaluate whether or not there is a chemical reaction taking place when sodium hydroxide is mixed with phenolphthalein, when writing on a paper with crayons, or when mixing colored liquids. He presented other everyday examples such as passing gas ("farting"), and asked students about the indicators, if any, that might suggest a chemical reaction had occurred for each phenomenon. He used the passing gas example to introduce the idea that gases can be warm and introduced the words "exothermic" and "endothermic" in relation to the release or absorption of heat during a chemical reaction. Mr. Ramos then asked students about their knowledge regarding these reactions. Students talked about, among other things, "fire" and "a car" and "combustion engines". Mr. Ramos continued showing a couple of slides with pictures of a precipitate to give students a better understanding of this indicator.

Next, Mr. Ramos worked with students as a whole class to practice translating chemical reaction word problems into chemical equations. The word problems were provided on handouts, projected on the whiteboard, and read aloud by students. This guided practice was followed by students working through several similar problems on their own. The lesson concluded with Mr. Ramos leading a whole class discussion in which he clarified any questions related to the practice problems. Students were encouraged to explain what the problems "were asking" in their own words.

\section{Ms. Ziegler}

Ms. Ziegler is an Anglo European White teacher in the final semester of her student teaching. She taught a biology course for mostly ninth graders in a large, diverse high school. In the class we 
observed, the majority (seventeen) of students were White, six were Latino/Latina, four were African American, and one was Asian American. One of the students was officially designated as EBL. Students were seated at individual desks aligned in rows, facing the white board at the front of the room.

The observed biology lesson was a continuation of a unit on viruses and bacteria. The topic for the day's lesson, "Cell Wars," was written on the board. In a previous lesson, Ms. Ziegler introduced students to the biochemical differences between a virus and a bacterium, including differences regarding how bacteria and viruses cause sickness and disease in humans and other species. Ms. Ziegler continued this topic, focusing on the immune system. She began the lesson by referring to examples from the previous day's lesson, "We decided yesterday that the common cold was a virus, right?" Ms. Ziegler asked students to share what they remembered about viruses from the previous lesson. Using their notes, students volunteered responses such as specific diseases caused by viruses, such as AIDS, chicken pox, and other examples.

Ms. Ziegler transitioned the lesson into the topic of immunity by commenting on the idea that humans survive many encounters with viruses: "I mean, there are so many viruses in the world and we'd all be dead if they killed us every time. So, we're going to talk today about how your body fights those off." Ms. Ziegler then introduced a metaphor to explain immunity in regard to viruses: "Your body is going to go through this process of creating, basically, an army to attack these viruses." As she described the process of how white blood cells fight off 'invaders,' she used a document camera ${ }^{4}$ to write and display key words on the screen at the front of the room. Students took notes and recorded key vocabulary in their graphic organizers. Ms. Ziegler encouraged students to draw their own representations for each word, and to use their own words when writing definitions:

What I want you to do is draw a white blood cell that's going to eat something. I'm going to draw mine like a Pac-Man. The first thing it's [the white blood cell] going to do is it's going to eat that virus. And it's going to eat that virus with something called a macrophage. [Ms. Ziegler used the document camera to project the word macrophage as she wrote it and repeated the pronunciation and spelling for students as they wrote the word on their graphic organizers.] Those are actually white blood cells. Okay and that's going to be like the front-line defender of your army... So, it's going to eat the invader and then it's going to pick up the virus antigens. It's going to display them on its own surface. So it's going to show those antigens on their own surface [draws an example]... So you can write "show" or "display." Then it's going to call to its friends, it's going to call the helper T cells...And they're going to act like the General of your army.

\footnotetext{
${ }^{4}$ A document camera is a device used to capture and project real-time images of documents.
} 
Ms. Ziegler continued using the "cell wars" metaphor and drawing/projecting her representation to explain how $\mathrm{T}$ cells and B cells work together to produce antibodies. She also integrated common examples from students' everyday experiences:

"You guys know that when you're getting sick sometimes you get sore swollen lymph nodes. Those are your killer $\mathrm{T}$ cells rushing to your lymph nodes and reproducing the antigens...That's your body fighting an infection (...) This is why when you get a virus your body builds antibodies for it and you don't get it again or as bad. Has anyone got the chicken pox?... And you usually don't get it twice. And that's why. Because your body can build up antibodies for it... and you've got memory cells that are going to remember that virus for a long long time."

Ms. Ziegler also told students about how her mother purposefully exposed her to chicken pox to protect her from getting shingles as an adult, and how--since the development of vaccinations for chickenpox--this purposeful exposure is not necessary. She used key terms from her lecture to explain how booster shots help build immunity, and how influenza vaccines are developed.

Next, Ms. Ziegler explained the culminating activity for this lesson. Working in groups, students would create a poster demonstrating the immune system's response to a virus. Ms, Ziegler asked students to come up with their own metaphor to illustrate and explain the process of the immune system at a cellular level and to include all the major components of the process. "You're going to create your own version of how this 'immunity army' works. You need to include all the components of the immune system that we have discussed." She gave them an example of using an African safari, where the ranger would be their B-cell and deploy the antibodies, so he might be throwing a net over the virus, for example.

And for your suppressor T-cells, that can just be, let's say you doing a war theme or Star Wars, that could be like a plane flying by with a banner behind it that says, "The war is over." Or we had some students who used an ocean theme and they had dolphins that were sending out ultrasonic signals saying, "Stop!"

As the students began to brainstorm ideas for their poster, Ms. Ziegler circulated among groups, inquiring about their ideas. One group stated they were using "Finding Nemo" as a theme. Another group explained their idea of using "Sponge Bob." A group of boys explained that they were going to use basketball or football as their theme. Ms. Ziegler asked the group about who would the virus be in that example. Students suggested a rival high school's football team as the virus. She then added, "so our football team could be the B-cells? And what would represent the antibody?" One student suggested, "the end zone." One girl and one boy discussed whether to use cars as a theme. The girl stated that she didn't know enough about cars but suggested maybe she would go along with it if they used the characters from the movie, Cars, which for her would be a more relevant context than cars in general. Moving to a different group, Ms. Ziegler asked students, "What are 
you guys going to do?" They responded, "Space Jam - the aliens are like the virus and then there's the Tomb squad and Michael Jordan are like the General 'cuz he's like leading everyone like the B-cells. The microphage is the Tasmanian devil." Ms. Ziegler probed, "What are your antibodies going to be?" Another group responded to her question about what they were going to do, "We are using a Zombie movie." Ms. Ziegler asked, "Who's going to be the virus?" They responded, "The teenagers. Macrophages are going to be the babies." Another group of students explained, "We are using soccer. The antibody would be the net of the goal and the forwards would be the B-cell, throwing it (the ball) out." Students continued to brainstorm and work on their poster for the remainder of the class period.

\section{Discussion: What Are We Learning from These Classroom Practices?}

Looking into these practices, we can see that Mr. Ramos connected complex phenomena to everyday language and phenomenon in the 'real' world. He encouraged students to make tangible connections to chemical equations and to scientific terminology. By drawing on everyday phenomenon (e.g. passing gas, car engines, fireworks, etc.), Mr. Ramos seemed to have aspired to create a linguistic "bridge", in which students could use a variety of familiar linguistic registers, grounded in their own experience of the world around them. This grounding allowed students to make sense of more abstract concepts and disciplinary language forms, such as leveraging mathematical representations of equations for understanding scientific notation of chemical processes. Mr. Ramos encouraged students to brainstorm and to use "their own words" to explain the scientific definitions he introduced. Mr. Ramos elicited examples from students' own experiences with chemical reactions and leveraged their responses by repeatedly asking them to discuss how they knew - what they can see, feel, etc., pressing them to connect those experiences to the scientific terminology that was introduced (indicators, product, reactant, etc.). Mr. Ramos also made connections to prior labs as a frame of reference for understanding chemical reactions.

Ms. Ziegler leveraged a supposedly familiar metaphor to help students understand the complex scientific concept of immunity. Unlike a 'hook' that serves as an anticipatory set for the lesson, Ms. Ziegler posed the "battle" or "war" metaphor as a common frame of reference for understanding how immune systems function, using this frame throughout her lesson, as a thread that connects learning to the disciplinary core ideas from one activity to the next. Moreover, she provided students the opportunity to develop their own metaphors by drawing from contexts that interested them. Student examples included references to sports and to popular culture (e.g., Sponge Bob, Finding Nemo, football, soccer, etc.). Ms. Ziegler attempted to establish a link between students' lived experiences or personal interests and science learning, providing feedback to check on the use of metaphors and the elements of the scientific content (e.g. asking which element of the chosen frame represented T-cells or antibodies). In this way, Ms. Ziegler provided a sustained opportunity for students to draw on and share their hobbies and interests as a vehicle for constructing more in-depth understandings of the topic at hand (immunity), and to demonstrate 
what they have learned in a more personally meaningful way. Furthermore, groups of students were able to discuss their viewpoints about what counts as relevant, as in the case the two students discussing whether to use cars in general vs. the movie Cars as a metaphor for their model. Ms. Ziegler also referenced other science-related social issues. For example, she mentioned her own experience with chickenpox and the cultural practice of exposing kids to other sick ones. She used this example to explain the immune system "memory" mechanisms and demonstrated relevance of the topic beyond the science classroom.

During the debrief interview following the lesson, Mr. Ramos expressed the importance of getting students to express science processes in both their own words as well as to use scientific terminology. He stressed that a focus on vocabulary and discourse was beneficial for all students. He also stated that he struggled with what he felt was his tendency to dominate classroom talk, and if he were to teach the lesson over again, he would make the following changes:

I want my lesson to be less of me talking and them doing more of the talking. I would like to only talk half of the time... I would have more demonstrations and also have students work in groups to have them come up with their own examples of chemical reactions and have students come up with their own examples and try to develop chemical equations that reflect those examples.

As we explore what Mr. Ramos said, we view attempts to demystify complex scientific language through connections with his students' experiences as an important, albeit preliminary, step in expanding opportunities to learn for EBLs in the classroom. We also note here a challenge: how the exclusive attention to science language, with cursory references to meaningful contexts, can also have the unintended effect of limiting possibilities for more contextually authentic science learning experiences. It could be that such attention to language learning as vocabulary instruction, without an overarching socio-scientific context for using language, can limit students' opportunities to use science and language in contextually authentic ways (Bruna, Vann, \& Escudero, 2007). Students in this lesson from Mr. Ramos are called on to make brief contributions to discussions of core ideas, and this occurs predominantly in a whole class format in which only one student can contribute at a time. From analyzing this lesson, we consider how we can design activities that would help pre-service teachers elicit students' experiences as central to the teaching event, rather than peripheral.

Mr. Ramos described the lesson as an introduction to the basic science language that would be used in increasingly more "applied" work later in the unit. We can infer that Mr. Ramos attended to the technical vocabulary of science, supported by English Language Development strategies intended to help students' make connections to more familiar contexts beyond school. In Mr. Ramos lesson, there was not an overarching theme or driving question in which the concept of chemical reactions was embedded, nor connections to a larger relevant issue or phenomenon that 
could be drawn on throughout the overall unit. What can we do in order to provide our pre-service teachers with clear strategies and habits of thought to contextualize science activities in meaningful or sustained ways?

On another note, Ms. Ziegler's reflection about her immune system lesson revealed that she wanted students to make sense of, and retain, the content through the lens of their own experiences and interests: "If they can contextualize the material on their own, they can hold on to it. I did that by allowing them to create a poster so they could come up with their own way to understand." (Debrief interview). Ms. Ziegler discussed how sharing her own experiences might help students make similar connections.

I like to tell them [students] little stories about my life. My hope is that my story will cause them to think of their own story. Like my story about having chicken pox, even though most of them are too young to have not had the vaccination, I hope it will spark their stories.

We have scrutinized and analyzed these two classroom practice events from the perspective of contextualizing science activities for facilitating meaningful learning for language use and development. We imagine how these two teachers might have planned and implemented their lessons differently, and what we might do in terms of rethinking our own practice as science educators to help better support them in doing so. We learned about the use of metaphor in Ms. Ziegler's efforts to contextualize instruction. There are questions that might yet to be answered: How can her approach actually limit or expand students' opportunities to make meaning of the complex scientific concept of immunity? Ms. Ziegler's hopes her examples helps students "hold onto" a scientific concept. How can students be equipped to use this information contexts outside of or beyond school science? As Mr. Ramos, Ms. Ziegler's primary focus appeared to be on decoding technical vocabulary. We might challenge ourselves in order to help build from this focus into developing functional literacies related to the concept under study.

In Mr. Ramos lesson, an example that has local relevance to the community, particularly for its residents, could have been used. The issue of toxicity and water contamination in this community, for example, could have significant importance to many students and their families. Potential themes/driving questions could be introduced related to toxicology, chemical structures of various solvents and other industrial chemicals and biochemical clean-up and remediation strategies. This theme could not only provide very real applied examples of chemical reactions and processes, but, more importantly, expand and facilitate connections between these science principles and health, environmental justice, local politics, and community economic issues. In addition, this topic would provide opportunities for students to develop their own questions about the contamination in their community through interviews with family members, field research, and use of government sources/reports. At a very introductory level, the use of the chemical reactions and processes related to major pollutants provides a concrete and contextualized doorway to the learning 
objective related to chemical equations and reactions. Students' voices, family knowledge and experiences related to this local issue could also be leveraged as important resources within the discussions and activities.

In Ms. Ziegler's lesson, a socioscientific and authentic framing could have come from current events related to viral transmission. For example, the recent and growing prevalence of the Zika virus or the 2014 Ebola Hemorrhagic Fever outbreak in West Africa (see Schindel \& Tolbert, 2016), or the measles outbreak in the Western United States could be contexts for engaging students in understanding not only the concept of immunity, but why immunity is an important global issue. Ms. Ziegler shared her own childhood experiences regarding chicken pox, and the powerful ways in which this is connected to the science content can actually justify an option of drawing on students' lived experiences as either having contracted chicken pox or having been vaccinated against it. Also, students could interview parents and other older family members about their experiences with chicken pox (or any other serious viral or bacterial-related illness). Knowing that stories about life experiences, including her own, are important, yet it seems that opportunities for students to share similar experiences with her could be more important for their learning.

\section{Implications for Teacher Learning}

We have learned from our inquiry into our teacher education practices and the examples from preservice teachers in classrooms that Contextualizing Science Activity is a complex and challenging practice for teachers to implement, which is consistent with prior research on socially and culturally contextualized science teaching. Teachers tend to rely on their own rather than their students' sociocultural experiences as frames of reference for instruction. They tend to make incidental rather than deep or sustained connections to students' lived experiences and funds of knowledge (Bravo et al., 2014; Patchen \& Cox-Petersen, 2008; Stoddart et al., 2013; Teemant et al., 2011). While complex and challenging, however, we view Contextualizing Science Activity as absolutely fundamental to teaching science with EBLs in multilingual classrooms, and thus, an integral part of science teacher education programs. This practice is an ambitious one, but we are encouraged by the slight shifts we have seen in analyses of the preliminary data from the first two years of the project (Lyon et al., 2018). These shifts are further elaborated in this article through the cases of Mr. Ramos, a preservice teacher from the baseline un-restructured cohort, and Ms. Ziegler, who participated in a redesigned science teacher education program. We have highlighted important differences between these two examples, particularly in terms of how Ms. Ziegler created limited but relatively more sustained opportunities for students to make sense of science. Students draw on the language and concepts of school science as well as their own experiences, interests, and discourses when they create their immunity metaphors, negotiating with peers what counts as relevant or not relevant (e.g., cars in general vs. the movie, Cars). This provides some encouraging evidence related to teacher learning in the area of contextualizing science activity, particularly when compared to our prior research in this area (Authors, 2013; 2014). 
These cases lead us to think about the supports we can provide in promoting a contextualized practice in science learning through teacher education. We should pay close attention to elements of our instruction that will provide more opportunities for learning. Working closely through sitebased collaborations with mentor teachers and science methods instructors who are unfamiliar, or less familiar, with the practice of contextualizing science activity should be the focus of future research. Also, emphasis should be put on the relationship of contextualizing science activity to language acquisition and science learning for EBLs. Both coaching and on facilitating contextually authentic learning experiences for EBL students should be part of the collaborations. We also recognize that induction support can play a key role in helping teachers develop ambitious practices, and, above all, support that facilitates novice teachers' "sense of membership in an ongoing reform community," (Thompson, Windschitl, \& Braaten, 2013) though this has not been part of our current project. Finally, we argue that a more robust theory of teacher learning is needed to better understand how novice teachers are able to contextualize science activity in multilingual classrooms over time - or not — as they move from their preservice student teaching experiences through their first few years of classroom teaching (Bianchini \& Cavazos, 2007; Patchen \& CoxPeterson, 2008; Thompson et al., 2013).

In the meantime, we continue to analyze and reflect about our teacher education practice and its impact upon the learning trajectories of novice teachers participating in our interventions. We continue to study and reflect upon how their learning varies over time and across contexts, as well as variations in practice that correlate with variations to novice teachers' own orientations and sense of agency in teaching science with/for students in multilingual classrooms.

\section{References}

Banilower, E. R., Smith, S. P., Weiss, I. R., Malzahn, K. A., Campbell, K. M., \& Weis, A. M. (2013). Report of the 2012 national survey of science and mathematics education (pp. 309). Chapel Hill, NC: Horizon Research, Inc.

Bianchini, J. A., \& Cavazos, L. M. (2007). Learning from students, inquiry into practice, and participation in professional communities: Beginning teachers' uneven progress toward equitable science teaching. Journal of Research in Science Teaching, 44(4), 586-612.

Bravo, M. A., Mosqueda, E., Solís, J. L., \& Stoddart, T. (2014). Possibilities and limits of integrating science and diversity education in preservice elementary teacher preparation. Journal of Science Teacher Education, 25(5), 601-619.

Bruna, K. R., Vann, R., \& Perales Escudero, M. (2007). What's language got to do with it?: A case study of academic language instruction in a high school "English Learner Science" class. Journal of English for Academic Purposes 6(1), 36-54.

Buxton, C. \& Allexsaht-Snider, M. (Eds.). (2016). Supporting K-12 English Language Learners in Science: Putting Research into Teaching Practice. London: Routledge. 
Callahan, R. M. (2005). Tracking and high school English learners: Limiting opportunity to learn. American Educational Research Journal, 42(2), 305-328.

Gándara, P., Maxwell-Jolly, J., \& Driscoll, A. (2005). Listening to teachers of English language learners: A survey of California's teachers' challenges, experiences, and professional development needs. Santa Cruz, CA: Center for the Future of Teaching and Learning.

García, O. (2009). Emergent bilinguals and TESOL: What's in a name? Tesol Quarterly, 43(2), 322-326.

González, N., Moll, L. C., \& Amanti, C. (Eds.). (2006). Funds of knowledge: Theorizing practices in households, communities, and classrooms. London: Routledge.

Iddings, A.C., Combs, M.C., \& Moll, L. (2012). In the arid zone drying out educational resources for English language learners through policy and practice. Urban Education, 47(2), 495514.

King, D. (2012). New perspectives on context-based chemistry education: using a dialectical sociocultural approach to view teaching and learning, Studies in Science Education, 48(1), 51-87.

Krashen, S. (1982). Principles and practice in second language acquisition. New York: Pergamon.

Krashen, S. (2013). The case for non-targeted, comprehensible input. Journal of Bilingual Education Research \& Instruction, 15(1), 102-110.

Lucas, T. \& Grinberg, J. (2008). Responding to the linguistic reality of mainstream classrooms: Preparing all teachers to teach English language learners. In M. Cochran-Smith, S. FeimanNemser, \& D.J. McIntyre (Eds.), Handbook of Research on Teacher Education (3rd ed., pp. 606-636). New York: Routledge.

Lyon, E. G., Stoddart, T., Bunch, G. C., Tolbert, S., Salinas, I., \& Solis, J. (2018). Improving the preparation of novice secondary science teachers for English learners: A proof of concept study. Science Education, 102(6), 1288-1318.

Lyon, E. G., Tolbert, S., Solís, J., Stoddart, P., \& Bunch, G. C. (2016). Secondary science teaching for English learners: Developing supportive and responsive learning contexts for sensemaking and language development. Lanham, MD: Rowman \& Littlefield.

Markos, A.M. (2012). Mandated to learn, guided to reflect: Preservice teachers' evolving understanding of English Language Learners. Issues in Teacher Education, 21(1), 39-57.

Moje, E., Collazo, T., Carrillo, R., \& Marx, R. (2001). "Maestro, what is quality? Language, literacy, and discourse in project-based science. Journal of Research in Science Teaching, 38(4), 469-498.

National Science Teachers Association [NSTA] (2010). NSTA Position Statement: Teaching science and technology in the context of societal and personal issues. Available online at http://www.nsta.org/about/positions/societalpersonalissues.aspx

New Zealand Ministry of Education (2011). Te Kotahitanga: Results and findings. Available online at http://tekotahitanga.tki.org.nz/About/Results-and-Findings 
Organisation for Economic Cooperation and Development [OECD] (2018). The future of education and skills: Education 2030. Retrieved 19 April 2019 from https://www.oecd.org/education/2030/E2030\%20Position\%20Paper\%20(05.04.2018).pdf

Patchen, T., \& Cox-Petersen, A. (2008). Constructing cultural relevance in science: A case study of two elementary teachers. Science Education, 92(6), 994-1014.

Rivet, A., \& Krajcik, J. (2008). Contextualizing instruction: Leveraging students' prior knowledge and experiences to foster understanding of middle school science. Journal of Research in Science Teaching, 45(1), 79-100.

Rodriguez, A. J. (1998). Strategies for counterresistance: toward sociotransformative constructivism and learning to teach science for diversity and for understanding. Journal of Research in Science Teaching, 35(6), 589-622

Rodriguez, A. J., \& Kitchen, R. (Eds.). (2005). Preparing mathematics and science teachers for diverse classrooms: Promising strategies for transformative pedagogy. New Jersey: Lawrence Erlbaum Associates, Inc.

Rosebery, A. S., \& Warren, B. (Eds.). (2008). Teaching science to English language learners: Building on students' strengths. Arlington, VA: NSTA Press.

Stoddart, T., Bravo, M. A., Mosqueda, E., \& Solís, J. L. (2013). Restructuring pre-service teacher education to respond to increasing student diversity. Research in Higher Education Journal, 19, 1-19. Available online at http://www.aabri.com/manuscripts/121389.pdf.

Stoddart, T. \& Mosqueda, E. (2015) Teaching science to English language learners: A study of pre-service teacher preparation. Teacher Education Practice, 28(2-3).

Stoddart, T., Solis, J., Lyon, E. G., \& Tolbert, S. (2017). Preparing pre-service secondary teachers to teach science to English learners: Theory into practice. In Science teacher preparation in content-based second language acquisition (pp. 97-115). Springer, Cham.

Stoddart, T., Solis, J., Tolbert, S., \& Bravo, M. (2010). A framework for the effective science teaching of English language learners in elementary schools. In D. Sunal \& C. Sunal. Eds., Teaching science with Hispanic ELLs in K-16 classrooms, pp. 151-181. Charlotte, NC: Information Age Publishing.

Stoll Dalton, S. (January 1, 1998). Pedagogy matters: Standards for effective teaching practice. Research report. Center for Research on Education, Diversity, \& Excellence (CREDE). UC-Santa Cruz, Santa Cruz, CA.

Teemant, A., Wink, J., \& Tyra, S. (2011). Effects of coaching on teacher use of sociocultural instructional practices. Teaching and Teacher Education, 27(4), 683-693.

Thompson, J., Windschitl, M., \& Braaten, M. (2013). Developing a theory of ambitious earlycareer teacher practice. American Educational Research Journal, 50(3), 574-615.

Tolbert, S. (2016). Contextualizing science activity. In E. Lyon, S. Tolbert, J. Solis, T. Stoddart, \& G. Bunch, Eds., Secondary science teaching for English learners: Developing supportive and responsive learning contexts for sense-making and language development, pp. 59-78. Lanham, MD: Rowman \& Littlefield. 
Tolbert, S., \& Bazzul, J. (2017). Toward the sociopolitical in science education. Cultural Studies of Science Education, 12(2), 321-330.

Tolbert, S., \& Knox, C. (2016). 'They might know a lot of things that I don't know': investigating differences in preservice teachers' ideas about contextualizing science instruction in multilingual classrooms. International Journal of Science Education, 38(7), 1133-1149.

Tolbert, S., Stoddart, T., Lyon, E. G., \& Solís, J. (2014). The next generation science standards, common core state standards, and English learners: Using the SSTELLA framework to prepare secondary science teachers. Issues in Teacher Education, 23(1), 65-90.

UNESCO (2016). Education 2030: Incheon Declaration and Framework for Action for the implementation of Sustainable Development Goal 4: Ensure inclusive and equitable quality education and promote lifelong learning opportunities for all. Retrieved 19 Apr 2019 from https://unesdoc.unesco.org/ark:/48223/pf0000245656 